\title{
Mentored Research Scientist Development Award
}

National Cancer Institute

\section{Source}

National Cancer Institute. Mentored Research Scientist Development Award. NCI

Thesaurus. Code C20005.

To provide support for a transition period between postdoctoral training and an independent research career. 